\title{
VZTAH PSYCHOLOGIE A TEOLOGIE TÉŽ Z POHLEDU STUDENTU゚ TEOLOGICKÝCH FAKULT
}

LUDMILA BART Ů ŠKOVÁ, PETER TAVEL

1. Úvod

$P_{s}$ sychologie jako předmět výuky je v současné době součástí mnoha různých studijních vysokoškolských oborů. Obvykle nikoho nepřekvapuje, že tato disciplina může mít velký př́nos jak pro vlastní osobnostní rozvoj jedince, tak pro zvýšení kvality a efektivity profese, na niž škola studenty připravuje.

Své místo si psychologie našla také na teologických fakultách. Někteří studenti ji vítají s nadšením, jiní k ní přistupují o poznání racionálněji, další s odstupem a v neposlední řadě se najdou i tací studenti, kteří ve výuce psychologie na teologické fakultě vidí ohrožení své víry a „čistoty“ teologického učení. Následující zamyšlení by rádo přispělo k diskusi na toto téma, zdůraznilo prínos i rizika výuky a zabývání se psychologií v oblasti víry a teologie, vymezilo hranice jednotlivých oborů. Součástí článku je též anketa, která proběhla v akademickém roce 2010/2011 mezi studenty KTF UK Praha a CMTF UP Olomouc.

\section{Několik poznámek k pojmu „psychologie“}

„Psychologie má dlouhou minulost, ale krátké dějiny“, napsal H.Ebbinghaus. Nejvýznamnější slovenský badatel, zabývající se dějinami psychologie, J. Koščo vysvětluje vývoj psychologie souběžně s vývojem filozofie a ostatních věd. Jeho práce potvrzují, že zájem o sledování psychických (duševních) jevů je starý jako lidstvo samo. ${ }^{1}$ Samo užívání

1 Srov. BOROŠ, Julius - ONDRIŠOVÁ, Edita - ŽIVČICOVÁ, Eva. Psychológia. Bratislava: IRIS, 1999, s. 12. 
pojmu psychologie je poměrně nedávného data. ${ }^{2}$ Podle některých pramenů poprvé užil názvu psychologie v roce 1517 Marcus Marulus, ${ }^{3}$ pak Goclenius v roce 1590 . V roce 1594 vydal jeho žák O. Casmann dílo Psychologia anthropologica, sive animae humanae doctrina, avšak užívání pojmu psychologie se neujalo. Termínu psychologie se začalo užívat až na začátku 18. století, soustavněji však až s dílem I. Kanta. ${ }^{4}$

První systematické pojednání o „duši“, jejích složkách a či funkcích a její metafyzické podstatě 5 podal Aristoteles. Psychologie byla pěstována jako součást teologie (spekulativní nauka o duši), od dob Descarta též jako problém vztahu duše a těla, tedy jako tzv. „racionální psychologie“. Teprve s rozvojem přírodních věd ve druhé polovině 19 . století se začíná psychologie osamostatňovat jako samostatná věda. Nastává éra „psychologie bez duše“. Pojem duše byl nahrazen jinými, „méně problematickými“ pojmy (mysl, vnitřní zkušenost, vědomí, posléze chování). Pojem psychologie tedy postupně dostával zcela jiný obsah. ${ }^{6}$

\section{Vztah psychologie a teologie (resp. víry) v dějinách}

Od konce 19. století tedy vystupuje psychologie stále výrazněji jako empirická věda, stále je však patrná její spojitost s různými filosofickými východisky. ${ }^{7} \mathrm{~V}$ počátcích své „vědecké“ existence se však psychologie snažila osvobodit od vazeb filozofie a teologie a snažila se dokázat, že je svébytným a samostatným vědním oborem. Po vzoru jiných, tehdy také nově koncipovaných přírodních věd, se snažila prokázat svoji vědeckost užíváním „vědeckých“ metod, zejména metody pozorování a experimentu. Představitelé této „mladé“ vědy se někdy př́liš zjednodušujícími, až militantními či naopak příliš generalizujícími výroky a interpretacemi snažili odhalit a dokázat slabá místa víry a teologie („náboženství není nic jiného než...“), představitelé teologie v rámci obrany svého oboru a své víry odpovídali někdy podobným

2 Srov. MUSIL, Jiří V. Speciální psychologie. 1. vydání. Praha: Portál, 1995, s. 18.

3 Podle jiných autorů užil poprvé termín psychologie v 16. století P. Melanchthon pro tematiku duševního života. Srov. VACÍNOVÁ, Marie - LANGOVÁ, Marta. Vybrané kapitoly z psychologie. 1. vydání. Praha: Victoria publishing, 1995, s. 15.

4 NAKONEČNÝ, Milan. Základy psychologie. 1. vydání. Praha: Academia, 1998, s. 12.

5 Viz též SOUČEK, Rudolf. Stručné dějiny psychologie. Praha: Česká grafická unie, 1946, s. 8.

6 Srov. NAKONEČNÝ, M. Základy psychologie, s. 12.

7 Viz asi 200 různých teorií psychologie osobnosti, v nichž se odráží filozofické východisko patrně nejvýrazněji. Např. DRAPELA, Viktor J. Přehled teorii osobnosti. 2. vydání. Praha: Portál, 1998, 175 s. 
způsobem, což vedlo ke vzniku nesmiřitelného sporu „psychologie versus teologie“. Tento uměle „akademicky vytvořený“ spor, v němž byla moderní psychologie představována pouze jako experimentálně přírodovědecká psychologie a psychoanalýza, jako výraz světonázorového racionalismu, liberalismu a subjektivismu, byl zcela v rozporu $\mathrm{s}$ faktem, že $\mathrm{v}$ počátcích praktické teologie existovala jednota psychologie a víry. ${ }^{8}$ Psychologie se tehdy setkávala s budoucími duchovními pastýři uvnitř praktické teologie ve formě tzv. pastorální medicíny. Slibné počátky pastorální medicíny, jejíž významnou součástí byla též pastorální psychologie, však vlivem výše zmíněného konfliktu utrpěly závažné škody. Předpokládalo se totiž, že moderní, „vědecké“ psychologii je třeba se postavit antimodernistickým vymezením. Sama psychologie k tomuto postoji teologů - jak již bylo uvedeno - však bohužel přispěla svými nábožensko-kritickými a proticírkevními výroky. Toto duchovně historické trauma psychologie a teologie bylo ještě zvýrazněno Napomenutími Pia XII. a výroky Jana XXIII., kteří duchovním zakazovali vykonávat psychoterapeutickou praxi nebo se jí podrobovat. Teprve Druhý vatikánský koncil zahájil rozhodující obrat katolické církve ve vztahu k psychologii. ${ }^{9}$

\section{Druhý Vatikánský koncil a psychologie}

V konstituci Gaudium et spes se uvádí: „V pastoraci je třeba dostatečně brát na vědomí a používat nejen teologické zásady, nýbrž i objevy světských věd, především psychologie a sociologie, aby věřící byli vedeni k ryzejšímu a zralejšímu životu víry..."10

V dekretu o výchově kněží Optatam totius čteme: „At' se dbá na zásady křestanské výchovy; ty se musí doplňovat moderními poznatky zdravé psychologie a pedagogiky... bohoslovci mají být vedeni k patřičné lidské zralosti, která se projevuje především duševní vyrovnaností a schopností uváženě se rozhodovat a správně posuzovat události i lidi.“11 Dekret dále připomíná, že bohoslovci se mají „naučit použí-

8 Srov. BAUMGARTNER, Isidor. Psychologie a víra - orientace a podnéty k diskusi. Praha: Pastorační středisko, 1996, s. 5.

9 Srov. BAUMGARTNER, Isidor. Psychologie a víra. Teologické texty 1996, roč. 7, č. 5, s. 154-156.

10 II. vatikánský koncil. Gaudium et spes. In Dokumenty II. vatikánského koncilu, 1. vydání. Praha: Zvon, 1995, čl. 62.

11 II. vatikánský koncil. Optatam totius. In Dokumenty II. vatikánského koncilu, čl. 11. 
vat pomůcek, které může poskytnout pedagogika, psychologie nebo sociologie“. 12

Deklarace o křestianské výchově Gravissimum educationis v první kapitole uvádí: „S využitím pokroku v psychologii, pedagogice a didaktice se má dětem a mladým lidem pomáhat, aby harmonicky rozvíjeli své tělesné, mravní a rozumové schopnosti..."13

Citací z Dekretu o apoštolátu laiků Apostolicam actuositatem lze uzavř́t tento krátký exkurs, prezentující názor II. Vatikánského koncilu na spolupráci psychologie a teologie: „... at se pro všechny úseky apoštolátu zakládají dokumentační a studijní střediska nejen v oboru teologie, nýbrž i antropologie, psychologie, sociologie a metodologie, aby se tím lépe rozvíjely schopnosti laiků, mužů i žen, mladých i dospělých."14

\section{Psychologický institut L. Rully SJ15}

Na výroky II. Vatikánského koncilu o důležitosti a užitečnosti psychologie pro pastorační péči reagoval Luigi M. Rulla SJ se svými spolupracovníky. V roce 1971 založil Psychologický institut na Gregorianu v Římě, kde dlouhá léta přednášel. Tento Institut se snaží realizovat myšlenky II. vatikánského koncilu, který doporučoval - jak již bylo uvedeno výše - využívat nejen teologii, ale i ostatní vědy, zejména psychologii a sociologii pro zralejší prožívání víry. ${ }^{16}$

Podle Rullových dlouholetých zkušeností s vedením věřících lidí současný člověk potřebuje více než dříve rady psychologa či psychiatra a sahá po nich proto, aby mu nějak pomohly znovu vybudovat nebo vystavět, co je přirozené a co dosud nemělo př́ležitost se rozvíjet. Jak zdůrazňuje Rulla, člověk je nedělitelná jednota a není možné oddělovat sféru psychickou a psycho-somatickou od sféry duchovní. Lze v něm však tyto sféry rozlišit, působit více na jednu z nich, a tak člověku pomoci v plnějším rozvoji.

12 Tamtéž, čl. 20.

13 II. vatikánský kocil. Gravissimum educationis. In Dokumenty II. vatikánského konci$l u$, čl. 1.

14 II. vatikánský koncil. Apostolicam actuositatem. In Dokumenty II. vatikánského koncilu, čl. 32.

15 Volně dle TROJAN, Kazimierz. Potrzeby psychiczne i wartości, oraz ich implikacje religione. 1. vydání. Kraków: WAM, 2001, s. 8-10.

16 Srov. II. vatikánský koncil. Gaudium et spes, čl. 62. 
Rulla nepopírá, že zvláště v Polsku (i když ani naše socio-kulturní katolické prostředí nemá někdy od daného názoru daleko) lidé neradi vyhledávají psychologa či psychoterapeuta, protože návštěva tohoto odborníka je spojena se stigmatizující nálepkou duševní nemoci. Obecně se lidé raději přiznají k somatickým obtížím a skrývají duševní trápení.

Podobného př́stupu si můžeme dle Rully všimnout i v situacích, kde se jedná o psychologickou pomoc v duchovním rozvoji člověka. V seminářích a noviciátech se často využívá konzultace psychologa, aby zkoumal přirozenou vhodnost kandidáta k danému způsobu života. Role psychologa nebo psychiatra se tak často omezuje na to, aby diagnostikoval patologii. Rulla dokazuje, že psycholog a psychoterapeut může být člověkem, který hraje důležitou roli i v duchovním rozvoji svěřených lidí. Rullovy analýzy poukazují na to, že neexistuje reálný rozpor mezi předpoklady zdravého náboženství a zásadami zdravé psychologie. Člověk je psychofyzická jednota, proto musí teologie nějakým způsobem brát ohled na lidskou přirozenost člověka, stejně tak jako pravá psychologie musí zohledňovat duchovní součást této jednoty, kterou člověk vytváří. Psychologie a teologie se mohou navzájem stimulovat. Rulla však též upozorňuje na možná úskalí při využívání psychologie v pastorační praxi: varuje před tím, aby se psychologie nestala „náboženstvím“, ale aby pomáhala dosáhnout hlubších vrstev člověka. Samotná psychologie totiž nedokáže odpovědět na otázky člověka týkající se jeho vztahu k Absolutnu. Rulla psychologii neabsolutizuje, ale ukazuje, že může pomoci člověku v jeho duchovním růstu. Jak uvádí, nelze totiž oddělovat duchovní rozvoj od lidského, osobnostního, protože tyto oba rozměry jsou na sobě závislé a vzájemně se podmiňují. Uvedené výroky dnes již čtenáře nešokují; je však třeba si uvědomit, že Rulla začal své výzkumy zhruba před čtyřiceti lety. Uznává prvenství působení milosti, ale jeho práce zároveň ukazují, že se člověk ve svém jednání řídí také danými zákonitostmi. ${ }^{17}$

17 Srov. též DYREK, Krzysztof - KOZUCH, Mieczyslaw - TROJAN, Kazimierz. Kněžské a řeholni povolání. 1. vydání. Kostelní Vydří: Karmelitánské nakladatelství, 1995, s. 15-34. 


\section{Vztah psychologie a spirituální teologie}

Podle Vojtěch Kohuta OCD lze vypozorovat čtyři teorie o vztahu přirozenosti a milosti, jinými slovy o vztahu psychologie a spirituální teologie. ${ }^{18}$ První, dnes již opouštěná teorie autonomie, předpokládá, že se obě vědy pohybují na dvou na sobě nezávislých rovinách. Mezi psychologií a spirituální teologií tedy není žádný vzájemný vztah, žádné ovlivňování, žádné přesahy. Teorie paralelismu, někdy též zvaná maximalistická tendence, naproti tomu udává, že se většinou duchovní rozvoj podřizuje rozvoji duševnímu. Toto řešení však relativizuje Boží transcendenci, proto se teologovi jeví jako nepřijatelné. Reakcí na tuto teorii je teorie konstrastu, známá též pod názvem minimalistická tendence. Tento pohled nejen že zdůrazňuje rozdíly, ale hovoří též o rozbíhavosti, protiřečení obou sfér. Tato teorie staví milost do rozporu s přirozeností. Jako nejpřijatelnější se jeví teorie koexistence (též umírněného paralelismu), která říká, že mezi psychologií a duchovním životem existuje vzájemný vztah a vliv, který je oboustranný.

Psychologie může v rámci spirituální teologie - dle Kohuta - plnit různé funkce: preventivní (psychické danosti člověka, které je třeba mít na zřeteli), očistnou (motivace duchovního života, terapeutickou (pomoc při odstraňování nejrůznějších traumat a patologie), pedagogickou (pomoc při duchovní formaci) a integrační (spolupráce na duchovním růstu jednotlivců a společenství). ${ }^{19}$

\section{Možný přínos psychologie v pastorační péči}

Andrej Dermek SDB uvádí ve svém příspěvku na semináři „Psychológia a pastorácia“, který byl zorganizován pro kněze a odborníky pomáhajících profesí následující: „Kněží a psychologové se setkávají ve své profesi s člověkem, každý však ho vidí z jiného zorného úhlu“‘20 Od kněze se často očekává, že bude do určité míry schopen povolání psychologa suplovat. Důvěra ke knězi, vyplývající z jeho povolání, vede mnoho lidí k tomu, že prosí kněze o radu také v osobních

18 Zpracováno volně KOHUT, Pavel. Zákony lidské psychiky v duchovním životě. Teologické texty 1998, roč. 9, č. 3, s. 87-90.

19 Srov. KOHUT, Pavel: Co je spirituálni teologie? Kostelní Vydří: Karmelitánské nakladatelství, 2007, s. 87.

20 DERMEK, Andrej: Čo očakávajú kňazi od psychológov a čoho sa obávajú. In Psychológia a pastorácia, zborník prednášok. Bratislava: Špirála, 1991, s. 59. 
otázkách. „Joint Commission of Mental Illnes and Health“21 provedla ve Spojených státech amerických obsáhlý výzkum. Základní otázka zněla: „Na koho se obracíte se svými osobními problémy?“ Ukázalo se, že z dotázaných vyhledalo kněze jakožto první volbu $42 \%$ respondentů, $29 \%$ se obrátilo na praktického lékaře a pouze $18 \%$ na psychiatra nebo psychologa. Zbývajících 11 \% bylo rozděleno mezi ostatní pomáhající profese. Výzkum ukázal, že zatímco za knězem či lékařem přicházeli lidé z vlastního rozhodnutí, ostatní zdroje pomoci byl vyžívány většinou na doporučení druhých. Průzkum přinesl i další poznatky. Existují jen malé odchylky, co se týká druhu problémů, s kterými se lidé obraceli na kněze, lékaře či psychiatry. Nejčastěji přicházeli lidé dle výzkumu ke knězi s manželskými problémy. V celkovém zpracování, dle hodnocení jednotlivých respondentů, byli nejlépe hodnoceni právě kněží a lékaři. Tento průzkum prokázal rozhodující roli kněží a lékařů jakožto těch, kdo jsou (u věřících) kontaktováni jako první v př́padě osobních problémů.

Na základě ankety provedené mezi kněžími pražské diecéze si duchovní tyto skutečnosti uvědomují a mají zájem o poznatky z oblasti psychologie a psychiatrie; dle jejich svědectví jim mohou tyto vědomosti a dovednosti ulehčit v pastorační činnosti. Zájem kněží se týká několika oblastí: poznání zákonitostí obecné a vývojové psychologie, včetně důležitých krizových úseků života, základy sociální psychologie, kdy žádanými tématy byla komunikace, vztah, práce se skupinou a hranice. ${ }^{22}$

Dle Opatrného má „psychologie posloužit knězi k tomu, aby lidem lépe rozumèl“.23 Důležitý, i když jemný rozdíl mezi psychologií a pastorační péčí, je dle zmíněného autora v cíli a v nástrojích působení. Cílem působení duchovního je obvykle duchovní růst, cílem práce psychologa je obvykle zvládnutí života. ${ }^{24}$

Již zmíněný Dermek vypočítává, co kněží v pastoraci od psychologie očekávají a čeho se obávají: 25 kněží očekávají jednoduše pomoc v přípravě na kněžství, při výkonu kněžského povolání, v duchovním doprovázení, pomoc při formování formátorů, pomoc formou různých

21 Srov. JOHNSON, Paul. Psychologie der pastoralen Beratung. Wien: Herder and Co., 1969, s. 32-33.

22 Srov. STAJNEROVÁ, L. Aplikace psychologie a psychiatrie v pastorační péći. Rukopis, diplomová práce, 2002, s. 36.

23 BAŠTECKÁ, Bohumila - GOLDMANN, Petr. Základy klinické psychologie. 1. vydání, Praha: Portál, 2001, s. 57.

24 Srov. tamtéž.

25 Zpracováno volně dle sborníku Psychológia a pastorácia, s. 60-63. 
kurzů, seminářů, školení a doporučené literatury. Obávají se toho, aby psychologie nepřekračovala své hranice a nechtěla nahradit v procesu spásy teologii, aby lidská věda nechtěla nahradit Boží milost.

I. Baumgartner konkretizuje tato očekávání následovně: psychologie může pomoci při růstu a zrání lidské osobnosti, včetně integrace sexuality at již v zasvěceném či nezasvěceném životě, může pomoci při léčbě „náboženských“ neuróz, při úpravě vztahů osobních i komunitních. Člověk, který žije v „nábožensky vadných postojích“ obvykle totiž netrpí nedostatkem teologicko-náboženských informací, nýbrž strachem, pocity viny, potlačovanou bolestí a zlostí. Proto mu často nepomáhají sebelépe míněné informace o víre a diskuse o ní, i když toto sám žádá, spíše potřebuje odhalit a uzdravit svůj zmatený citový svět. ${ }^{26}$ Závažným a dosti častý problémem v pastoraci bývají tzv. ekleziogenní neurózy, duševní poruchy, na jejichž rozvoj mám vliv přísná a nelaskavá náboženská výchova. Nezdravá náboženská výchova, která je založena pouze na tom, co se „má“ a „musí“, může vytvořit v dítěti patologický obraz Boha. ${ }^{27} \mathrm{Na}$ Boha pak přenášíme mnohé z toho, co jsme v dětství zakusili ve vztahu k svým rodičům. Důsledkem toho pak může být zúžení obrazu Boha na infantilní obraz otce a matky, a to někdy i na celý život. Subjektivní představa Boha je pak zaplněna nezpracovanými relikty, potlačenými a trvajícími pocity strachu, bolesti, zlosti a méněcennosti, jež pocházejí z historie našeho vlastního života. ${ }^{28}$ Psychologie nám může pomoci, abychom uzdravením našich životních traumat dozráli k očištěnému vztahu k Bohu. Psychologie však nemusí být cestou jedinou. Výše uvedenou problematiku vztahu psychologie a teologie dobře shrnují slova psychologa Petra Goldmanna: „Psychiatr a psycholog mohu věřícímu pomoci k tomu, aby svou víru zase mohl dobře a zdravě užívat.“29

\section{Anketa mezi studenty KTF UK a CMTF UP}

V akademickém roce 2010/2011 proběhla mezi studenty KTF UK a CMTF UP anketa, která měla za úkol zjistit, s jakými postoji, názory a očekáváními ve vztahu k psychologii přistupují studenti ke studiu psychologie. Respondenti odpovídali na dva okruhy otázek:

26 Volně dle BAUMGARTNER, Isidor. Psychologia a víra. Teologické texty 5/96, s. 155.

$27 \mathrm{O}$ této problematice pojednává např. FRIELINGSDORF, Karl. Falešné představy o Bohu. 1. vydání. Kostelní Vydří: Karmelitánské nakladatelství, 1995, s. 19-27, 87-145.

28 Srov. BAUMGARTNER, I. Psychologie a víra. Teologické texty 5/96, s. 155.

29 BAŠTECKÁ B., GOLDMANN, P. Základy klinické psychologie, s. 57. 
a) já a psychologie (jaký máte vztah k psychologii, setkal/a jste se s ní už někdy v životě, pokud ano - jakým způsobem; co si o psychologii myslíte),

b) psychologie a KTF UK (resp. CMTF UP) - jaký je Váš názor na výuku psychologie na fakultě, patří psychologie do výuky na teologických fakultách, jaká máte od tohoto předmětu očekávání.

Ankety se zúčastnilo celkem 95 studentů: 49 posluchačů z CMTF UP, 46 posluchačů z KTF UK. Většina respondentů měla k psychologii pozitivní vztah (43 studentů CMTF UP, 31 studentů KTF). Neutrální vztah k tomuto oboru uvádí 4 lidé z olomoucké a 10 lidí z pražské fakulty. Na CMTF UP byl v rámci ankety zaznamenán jeden výrazně negativní vztah k psychologii („považuji psychologii nejen za nepotřebnou, ale doslova atraktivní pavědu; podává informace, které jsou z jiných duchověd, Geistwissenschaft, také dosažitelné“). Na KTF UK jeden respondent udává velmi střízlivý vztah, další tři velmi negativní vztah k psychologii („připadá mi, že se jde s kanónem na vrabce, svoje problémy řeším spíše postupně na základě ,křestanství a svého vztahu k Bohu... otázka je, zda lidem spíše neprospěje láska než psychologie, takoví lidé se do ostatních vcítí... psycholog není Pán Bůh!“).

A jaký je názor studentů na vztah psychologie a teologie? 48 studentů CMTF UP a 40 studentů z KTF UK jsou toho názoru, že výuka psychologie na teologické fakulty patří. Tito studenti vnímají psychologii jako obor, který je nezbytný pro pochopení sebe i druhých, má úzkou návaznost na pastorální i spirituální teologii („,... psychologie na KTF se mi jeví jako prospěšný předmět, protože na člověka nelze hledět pouze skrze teologické brýle. Teolog by se měl snažit pochopit člověka ne pouze očima víry..."), přispívá ke komplexnějšímu pohledu na člověka. Psychologie a teologie se tedy nevylučují, ale doplňují. Někteří respondenti upozorňují na to, že psychologie i teologie se překrývají („hranice duchovna a duševna je vždy dosti hraniční a překrývající se..."), psychologie i přes svou užitečnost zůstává pomocnou disciplínou pro teologii, nemá absolutní hodnotu a není samospasitelná („... psychologie má pomáhat, není zárukou spasení a navíc přílišné lpění na ní může opomíjet Ducha svatého a jeho dílo. Psychologie je dobrá, ale má své hranice. Bůh tyto hranice může bořit, stavět i posouvat... Psychologie je dobrým pomocníkem, ale musí se brát jen jako pomůcka. Hlavní důraz se musí samozřejmě klást na Boha a na pomoc lidem skrze Něj:“). V některých odpovědích se skrytě zrcadlí výše uvedený spor teologie a psychologie (,... to, že se předmět vyučuje v rámci teologické fakulty, znamená určitý respekt před poznatky psychologie 
z hlediska teologů... dobrý kněz by neměl vylučovat pomoc psychologa a dobrý psycholog by měl počítat s pomocí kněze. Naprosté uzdravení člověka není v lidských rukou...").

Psychologických poznatků lze tedy významně využít ve prospěch jednotlivců i skupin, ale má své hranice, které musíme respektovat. Psychologii lze i zneužít (,... psychologie je velmi neužitečná až nebezpečná, pokud se snaží využívat neadekvátních prostředků a metod a pokud se snaží suplovat funkci náboženství a stává se jakýmsi ,kvazináboženstvím s mystickými prvky“...").

\section{Závèr}

Lidská zkušenost, ale i teoretická reflexe ukazuje, že psychologie a teologie (zejména pastorální a spirituální) jsou obory, které nemusí stát a nestojí nesmiřitelně proti sobě ve snaze pomoci člověku k plnějšímu životu. Oba tyto obory (jako každý jiný vědní obor), mají svou metodu, předmět, své limity a hranice. Ukazuje se jako velmi prospěšné pro všechny zúčastněné, pokud psychologové i teologové, s vědomím těchto hranic, dokáží společně spolupracovat k dobru člověka. Výuka psychologie na teologických fakultách může přispívat k vzájemnému porozumění těchto dříve někdy nesmiřitelných oborů.

\section{ABSTRACT \\ LUDMILA BARTU゚ŠKOVÁ, PETER TAVEL \\ Relationship between psychology and theology, also from theology students' view}

The relationship between psychology and theology took many different shapes in the past. Insufficient respecting of the boundaries of fields together with misapprehension led to conflicts, the impact of which has often persisted until now. A clear word into this argument was brought by the Second Vatican Council. The cooperation between psychology and pastoral or spiritual theology can be very beneficial in practice. The results of the poll taken in KTF UK and CMTF UP are a part of the article.

\section{Key words}

psychology, theology, pastoral care, spirituality, religious neuroses 